\title{
Lumen
}

Selected Proceedings from the Canadian Society for Eighteenth-Century Studies

\section{Madness as Shelter for Feminist Ideas: Elinor's Role in Frances Burney's The Wanderer}

\section{Victoria Kortes-Papp}

Volume 18, 1999

Representations of Time in the XVIIIth Century

Le temps et ses représentations au dix-huitième siècle

URI : https://id.erudit.org/iderudit/1012369ar

DOI : https://doi.org/10.7202/1012369ar

Aller au sommaire du numéro

Éditeur(s)

Canadian Society for Eighteenth-Century Studies / Société canadienne d'étude du dix-huitième siècle

ISSN

1209-3696 (imprimé)

1927-8284 (numérique)

Découvrir la revue

Citer cet article

Kortes-Papp, V. (1999). Madness as Shelter for Feminist Ideas: Elinor's Role in Frances Burney's The Wanderer. Lumen, 18, 95-106.

https://doi.org/10.7202/1012369ar

Copyright (c) Canadian Society for Eighteenth-Century Studies / Sociéte canadienne d'étude du dix-huitième siècle, 1999
Ce document est protégé par la loi sur le droit d'auteur. L'utilisation des services d'Érudit (y compris la reproduction) est assujettie à sa politique d'utilisation que vous pouvez consulter en ligne.

https://apropos.erudit.org/fr/usagers/politique-dutilisation/ 


\section{Madness as Shelter for Feminist Ideas: Elinor's Role in Frances Burney's The Wanderer}

Madness is ever present in Frances Burney's creative works. Her exploration of the theme is at its peak in her four tragedies, written during her five years of service at court as Second Keeper of the Robes to Queen Charlotte, starting in 1786 and lasting until 1791, spanning the time in which George III's madness was at its height. The King's illness profoundly affected the entire royal household, and Burney's journal entries for the years 1788 and 1789 reflect its impact on her life by their abundance of details regarding his state. Her creative outlet during this difficult time was in the construction of these tragedies, in each of which the heroines react with episodes of madness to the violent and chaotic acts to which they are subjected. But Burney's fascination with madness precedes her time at court. The theme is broached, if somewhat timidly, in her first novel, Evelina, or, A Young Lady's Entrance into the World (1778), where a minor character, Macartney, is in a state of despair and attempts to commit suicide. Evelina is effective in dissuading him, not yet knowing that she is in fact saving her own brother's life. Madness is more boldly broached in Burney's second novel, Cecilia, or, Memoirs of an Heiress (1782), in which the character of Harrel, one of Cecilia's guardians, after threatening suicide on many occasions as part of a successful manipulation to obtain from Cecilia significant amounts of her fortune, finally and shockingly does take his own life. Throughout the novel, even while the reader believes Harrel's threats of self-violence to be idle, the soundness of his mental state becomes suspect in his increasing fits of anger. Harrel, however, is not the only character whose mental health is compromised: Cecilia has her own serious brush with madness. The first signs of it appear as a result of her undergoing extreme stress because of the difficulties surrounding her engagement to Mortimer Delvile, with a final provocation that comes when Cecilia believes Delvile to have been wounded in a duel. Her madness becomes manifested in an inability to speak, loss of consciousness, a refusal of food or drink, temporary paralysis, and being in a trance-like state. 
Burney's time in service at court in such extraordinary circumstances contributed to intensifying her focus on the theme of madness in her later novels. Madness has a crucial part in her third novel, Camilla, or, A Picture of Youth (1796). Here, added to the symptoms experienced by the heroine in Cecilia, are violent nightmares and hallucinations experienced by Camilla at a time when she finds herself cut off from her family, riddled with misplaced feelings of guilt for their financial difficulties, and heartbroken in her belief that she has forever lost her love object, Edgar Mandlebert. Suffering dreadfully from her alienation, and unable to imagine any bearable outcome to her troubles, she comes to believe that only death can deliver her, and, as a product of the various hysterical physical symptoms she experiences, thinks herself to be actually dying. The theme unfolds by having the heroine not only suffer madness which the reader can observe through symptoms, but actually having her act it out in dreams, with the reader as witness to what goes on in her mind. She has a fantastic dream in which she encounters death personified. In it, Death hands her a pen of iron which compels her to write madly against her will, a sequence that has captured the interest of many critics and which is now often associated to Burney herself. Madness also plays a central role in Burney's final novel, The Wanderer; or, Female Difficulties (1814), where it is mostly concentrated in an important secondary character, Elinor Joddrel. This paper will analyse the character of Elinor, and the role her madness plays in the novel.

The role of Elinor in The Wanderer is interesting on several counts. Although she is not the novel's heroine, her significance is underlined to the reader in many ways. We are introduced to her at the very opening of the novel, where she is present with Juliet, the work's heroine, on the ship which provides them a covert route from France during Robespierre's reign of terror, to the safety of England's shores. Conversely, the problem which Elinor poses is one of the last difficulties addressed by Juliet and the novel's hero, Harleigh, at the very end of the novel. In addition, scattered throughout the work, Elinor makes many appearances that have a pivotal effect on the unfolding of the events of the narrative. Several of her appearances are in the form of ambushes during which she makes extravagant and often comical suicide attempts. Alongside these she provides an ongoing recitation on numerous ideological points, most importantly on questions of justice and women's rights.

Elinor is also an unusual character, especially in that, unlike the other major characters of the novel, it is not clear what readers are meant to feel for her, sympathy or antipathy; are we meant to perceive her as meriting respect or think her only deserving ridicule? This ambivalence can be attributed to the fact that Burney does not make clear to the reader 
whether Elinor is friend or foe to Juliet, while there can be no doubt that Burney intends her readers to find greatest sympathy with Juliet, the novel's heroine. Although in several parts of the text Elinor is Juliet's only supporter, through much of the novel Elinor feels great mistrust toward Juliet, mainly because of the threat she rightfully perceives Juliet poses to Elinor's love-relationship, or rather, her imagined love-relationship, with Harleigh. As we as readers naturally tend to side with Juliet, our liking for Elinor can be made to rise and fall with the condition of their friendship. But if the question of sympathy is set aside, we cannot help but be fascinated by Elinor, her passion and radicalism, in her words and in her actions, and we are interested in the many paradoxes that find in her a home. But in addition to her ambivalent treatment of Juliet, the greatest obstacles to having Elinor be a trustworthy and credible character are her exhibitions of madness. There is instance after instance in which she manifests lack of control of her emotions, and displays desperate acts and various other extreme and erratic forms of behaviour.

At the opening of the novel the reader encounters Elinor as Juliet first encounters her, merely as an eccentric. Her family seems accustomed to her often odd and unpredictable conduct. In fact, Elinor appears on several occasions to take advantage of the shock value of her actions by consciously manipulating family members to act against their better judgement in order to avoid what she promises to be an embarrassing pageant of her wide arsenal of antisocial behaviour. But regardless of Elinor's peculiarities, Juliet finds her to be agreeable enough, even as she gives her the following mixed review. She describes her as having:

a solid goodness of heart, that compensated for the occasional roughness, and habitual strangeness of her manners. Her society was gay and original; and, to great quickness of part, and liberality of feeling, she joined a frankness of character the most unbounded. [...] Upon chosen and favourite subjects she was impressive, nay eloquent; upon all others she was careless, flighty, and indifferent, and constantly in search of matter for ridicule: yet, though severe, almost to ferocity, where she conceived herself to be offended, or injured, she became kind, gentle, and generously conceding, when convinced of any errour. (The Wanderer, 77)

As the novel unfolds, however, it becomes clear that Elinor is not merely eccentric, but that from events that precede the start of the novel, her mental health is compromised. She had been in France prior to the beginning of the novel's action because she had been ordered there to attempt to recover from the emotional turmoil of being engaged to (Albert) Harleigh's brother, Dennis, whom she did not love, and 'the conflict of her mind, during this doubting state, threatened to cast her 
into a consumption' (The Wanderer, 155). In "'Turning the World Upside Down": Madness, Moral Management, and Frances Burney's The Wanderer', Justine Crump underlines how 'the mental origin for this apparently bodily illness suggests that her disorder is hysterical', adding that 'in eighteenth-century terms, such a translation of emotional disease into bodily illness is practicables' (331). Elinor found her time in France therapeutic, if not in the sense she would have expected on the outset. Her time in France had introduced her to revolutionary ideology which, as it applied to the distress she was experiencing in regard her undesired engagement, was as liberating as it was captivating. She tells Juliet and Harleigh:

[y]ou think me, I know, tarnished by those very revolutionary ideas through which, in my own estimation, I am ennobled. I owe to them that I dare hold myself intellectually, as well as personally, an equal member of the community; not a poor, degraded, however necessary appendant to it. I owe to them my enfrancisement from the mental slavery of subscribing to unexamined opinions, and being governed by prejudices that I despise: I owe to them the precious privilege, so shamefully new to mankind, of daring to think for myself. But for them should I not, at this moment, be pining away my lingering existence, in silent consumption? They have rescued me from that slow poison! (The Wanderer, 173)

Unfortunately, notwithstanding Elinor's own view of the benefits she gained, in the eyes of her immediate society in England, her time in France had done nothing to cure her. Her pursuit of Harleigh as her love object is what has her acting out in the most outrageous ways. She attempts suicide four times, though seldom do these attempts have physical repercussions that cause serious alarm. She in part makes these attempts as a way of engaging Harleigh's emotions, emotions to which she otherwise has little access:

[...] Elinor appeared in deep mourning; her long hair, wholly unornamented, hanging loosely down her shoulders. Her complexion was wan, her eyes were fierce rather than bright, and her air was wild and menacing.

"Oh Harleigh! adored Harleigh!" she cried, as he flew to catch her desperate hand; but he was not in time; for in uttering his name, she plunged a dagger into her breast.

The blood gushed out in torrents, while, with a smile of triumph, and eyes of idolizing love, she dropt into his arms, and clinging round him, feebly articulated, "Here let me end! accept the oblation the just tribute of these dear, delicious, last moments!" (The Wanderer, 359) 
In the way Elinor acts, she seems desperate that Harleigh should know that she is serious about killing herself. In fact because of her dismal successes in her several attempts, one can surmise that she is more eager to show Harleigh that she is serious about killing herself because her feelings for him are not reciprocated, than she is actually serious about wanting to kill herself. Of her third suicide attempt, again staged for Harleigh to witness, Elinor says self-deprecatingly: 'Tis again, then [...] abortive! - and a third time, I am food for fools, - when I meant to be food only for worms!' (The Wanderer, 579-80). Whether she intended to become 'food for worms' is open to debate. On the other hand, her attempts to harm herself, their many repetitions and their lack of impact, do in fact leave Elinor's actions appearing absurd.

In the novel, from the time of her first suicide attempt onward, Elinor's emotional and cognitive stability is constantly in at least some measure of doubt for the reader; to what extent is a question that is left to be determined still. In Frances Burney: The Life in the Works, Margaret Anne Doody expresses the opinion that the suicide attempts are in fact not meant to discredit Elinor, but serve instead to place her more squarely in the feminist camp:

[ $t$ ] he suicide threat is a testimonial to Elinor's allegiance to heroic dogma and Romantic modernism. In her suicide attempt she is very visibly a disciple of Mary Wollstonecraft. After Godwin published his own "Memoir" of his wife in her Posthumous Works, the whole world knew of Mary Wollstonecraft's unsuccessful attempts at suicide, especially her leap from Putney Bridge in October 1795, in despair over rejection by her lover, Gilbert Imlay. Elinor is one of the suicidal feminists, then - those paradoxical strong-minded martyrs to sensibility, whose revolutionary principles bid them ignore the canon 'gainst self-slaughter. (342)

But even if Elinor's madness acts at least in part to compromise her credibility with the reader, it is nevertheless apparent that, like other rebellious characters, such as Emma in Mary Hay's Memoirs of Emma Courtney (1796), or Harriet Freke in Maria Edgeworth's Belinda (1801), Elinor holds opinions that voice important insights into the circumstances and events of the novel as a whole, and does so in a way that other characters are barred from doing. Woven into scenes that show her unwellness, Burney presents us an Elinor who is deeply and coherently engaged in an intellectual and ideological dialogue with the world around her.

Elinor's sense of justice is not the same as the world's sense of justice, and during her many appearances in the work, she expresses clearly her perceptions and opinions, as here on the way men judge women, in contrast to the way men are judged by other men: 
[b]y the oppression of their own statutes and institutions, they render us insignificant; and then speak of us as if we were so born! [...] To be condemned, as weaker vessels in intellect, because, inferiour in bodily strength and stature. [...] They assert not that one man has more brains than another, because he is taller; that he is endowed with more illustrious virtues, because he is stouter. They judge him not to be less ably formed for haranguing in the senate; for administering justice in the courts of law; for teaching science at the universities, because he could ill resist a bully, or conquer a footpad! No! Woman is left out in the scales of human merit, only because they dare not weigh her! (The Wanderer, 399)

Equality among the sexes (what the The British Critic in its 1814 review of The Wanderer refers to as Elinor's egalité mania) is one of her foremost concerns, as is shown by many of her remarks to Harleigh:

[...] the Rights of woman: Rights, however, which all your sex, with all its arbitrary assumption of superiority, can never disprove, for they are the Rights of human nature; to which the two sexes equally and unalienably belong. (The Wanderer, 175)

While in several of Elinor's speeches a Wollstonecraftian influence can be noticed, the editors of the Oxford World's Classics (1991) edition of The Wanderer note that Burney, by having Elinor use the words 'Rights of Women', makes a direct reference to Wollstonecraft's work (The Wanderer, note to page 175). Also on the double standard in society's treatment of men and women, in this case as it particularly pertains to Juliet's ambivalence toward asserting her right to making a living, Elinor says:

[t]hey require from her, in defiance of their examples! — in defiance of their lures! - angelic perfection. She must be mistress of her passion; she must never listen to her inclinations; [...] she must always be guided by reason, though they deny her understanding! (399-400)

Elinor's sharp criticism of the social order, and therefore Burney's depiction of it, elicited much negative response in critics of the day. In addition, just as early critics of The Wanderer were disappointed that Burney did not paint revolutionary France more negatively, they were also quick to notice that Elinor's portrayal, despite its trappings of madness, was not wholly negative. In fact, Elinor's ideologies are not without their supporters in The Wanderer. Her behaviour is widely considered by the other characters as radical, even at times as deviant. But her opinions that pertain to the equality of the sexes and those that decry social injustice have no detractors among the main characters of 
the novel. Although, as Rose Marie Cutting points out, Harleigh 'predictably vanquishes Elinor's atheism in a lengthy debate on the immorality [sic.] of the soul', no one 'not even Harleigh or [...] Juliet, refutes Elinor's accounts of the injustices inflicted upon women' (60). In her 'Introduction to the Oxford World's Classics The Wanderer', Margaret Anne Doody adds that in the scenes of debate between the two women, Juliet's contribution is not retort, but amplification. She points out to middle-class Elinor the extent to which 'Female Difficulties' are not emotional but economic difficulties (xxx).

It is true that not only are Elinor's words on the subject of equality left uncontradicted, one can hear echoed in the words of other characters, most especially in the words of Juliet, Elinor's sentiment. Moreover, since Juliet is forced by her temporarily diminished economic and social circumstances to live for part of the story among working-class people and work side by side with them, she is often a closer witness to the injustices that Elinor deplores, and, were she inclined or able to speak out, would consequently be in a better position than Elinor to engage in debate on issues of social justice. This is most certainly the case in Juliet's work in the milliner's shop, and also so in Gabriella's shop, in which she sees the trials and injustices inflicted by tradespeople and shop-patrons. The difficulties she encounters in her real-life experiences also prevent her from romanticizing the working class, however. She sees the dishonesty pervasive in that level of society as well, even as she seems to want acknowledged that dishonesty there is fostered by the greater injustice of the ruling classes toward the working class. Rural life in The Wanderer is also judged with a critical eye by being shown to provide no protection to Juliet. Moreover, while in the country, she is given the opportunity of witnessing many injustices that occur there also, most especially as they are committed against women. As Judy Simons writes:

[t]he pastoral ideal is quickly demolished in Burney's acerbic view of rural life, where a farmer's wife exists as little more than a slave to the brutal whims of her despotic husband. Female labourers toil without relief and have the added torment of sexual harassment from casual predatory workmen. (Fanny Burney, 105)

The double standard of what makes for acceptable behaviour in men and women, frequently discussed by Elinor, is particularly deplored by Juliet:

[d]eeply hurt and strongly affected, how insufficient, she exclaimed is a FEMALE to herself! How utterly dependant upon situation - connexions circumstances! how nameless, how for ever fresh-springing are her DIFFICUL- 
TIES, when she would owe her existence to her own exertions! Her conduct is criticized, not scrutinized; her character is censured, not examined; her labours are unhonoured, and her qualifications are but lures to ill will! Calumny hovers over the head, and slander follows her footsteps! (The Wanderer, 274)

The truth of this statement cannot be more clearly illustrated than it is in poor Juliet's own life. She not only feels disadvantaged by the fact that she is without family and social connections to help protect her from the world, but she particularly feels disadvantaged by the fact that she finds herself a woman alone. The reader is made to share her frustration in having to wait for relief from sources beyond her control, unable to do anything to help herself, and being censured when she attempts to act in her own defence. She has to suffer people's judgements of her when her actions are blameless in every way, while several male characters, who are thought blameless by their society, are in fact guilty of transgressive, and sometimes immoral, behaviour. Over and over again we see her powerlessness to protect herself from insult; often only luck prevents her from injury.

It is not only by Juliet's words that we find her indirectly supportive of Elinor's notions. The injustices which Elinor denounces are often the very injustices which are encountered, not at an ideological level, but in reality, by Juliet in the course of the novel, as, with her identity hidden and without any family to protect her, she not only witnesses, but is herself exposed to all manner of dangers and unfair treatment. And so mad Elinor's ramblings, in a way that she herself could hardly imagine, tell the story of Juliet's experiences.

A key, therefore, to understanding Juliet lies in the way in which her character is paired in this central way to Elinor. In The Proper Lady and the Woman Writer, Mary Poovey explores the occurrence of this kind of pairing as a technique by which different facets of a heroine can be explored. Poovey's analysis proves fruitful to understanding The Wanderer:

Both Richardson and Defoe effectively use the technique of "doubling" their female characters, pairing, for example, the resigned, angelic Clarissa with intractable Anna Howe (or, for that matter, with the demonic Mrs. Sinclair), or the wealthy Roxana with her obedient maid Amy. Eighteenth-century women authors, from Eliza Haywood to Maria Edgeworth, used this technique, for it provided an opportunity not only to dramatize the negative counterparts of the heroine's perfect qualities but also to play at different roles, to explore, often through the characters of servants or lower-class women, direct actions forbidden to the more proper lady. (42) 
Juliet is in every way 'the proper lady' in this case; Elinor is neither a servant nor a lower-class woman, but her many irregular characteristics make for an effective converse to Juliet. There are many ways in which Juliet and Elinor are linked formally in the novel. Elinor provides Juliet her first home after their crossing from England. When Juliet is in financial distress, Elinor makes some efforts to provide her with work. And most importantly Elinor and Juliet are joined together, with Harleigh as their object, in the novel's love triangle. As Juliet's identity is hidden, readers find out her real name only late in the narrative: for the bulk of the novel, Juliet is known by the pseudonym of 'Ellis.' Doody, in her 'Introduction', mentions in particular that 'the similarity [in the names] of "Ellis" and "Elinor" alerts us to the possibility that these two characters may be seen as aspects of each other' (xvi). At the risk of overemphasizing the issue, this comparison may be expanded to say that Ellis's true name, Juliet, also has in common with Elinor Joddrel a first letter 'J.' The text seems in this to be indicating that in pseudonym as well as in given name, Ellis/Juliet and Elinor Joddrel are linked with one another.

It is interesting to consider the reason why the novel requires Elinor to, at least in part, speak for Juliet. Julia Epstein in The Iron Pen makes a good case for attributing it to having Juliet, until the point where her identity and her family connections are established, too powerless to risk further alienation: 'Juliet lives a necessarily defiant role in her namelessness, remaining ambiguous in nationality, marital status, and class as well as name. But while Juliet must maintain silence, Elinor, safely identified, can be read as speaking for her and expressing her resentment' (188). Juliet is the silent partner, but in crucial ways, she is partner to outspoken Elinor. In this important respect, we can see Juliet and Elinor as the two faces of the same coin: one silent, one loud, one entrapped by the injustices of her society, one financially and socially secure enough to make her observations about those injustices at leisure, while encountering some degree of social disapproval, is protected by her family and income so as not to be made a complete outcast.

Indeed, what would have happened to Juliet, in her circumstance, had she been as outspoken as Elinor? Would she have had any chance of survival in her already vulnerable condition, had she had anything more for which to be reproached? Had she expressed aloud her outrage of society's cruelty toward women and injustice to the working classes, would she still have been a good candidate to win Harleigh's heart? Juliet would not only have been in greater danger had she been outspoken, but she would not have been a very viable heroine, her delicacy being too deeply valued by all. In fact, Harleigh often shows himself dismissive of the gravity of her situation: he frequently demonstrates greater con- 
cern for her reputation as his future bride than for her immediate needs for a means of livelihood, as shown in his attempts to dissuade Juliet from her plans to perform in a subscription concert.

Elinor frequently speaks aloud what Juliet thinks only for the reader to hear, and it is possible Juliet would say more than she does if she had a greater power base to support her. In the end, however, it is difficult to imagine that Juliet, even if she were in a position to fully speak her mind, would speak it as Elinor speaks hers. Andrea Austin comments on the differences in the way the two characters exert power in the events of the novel:

Juliet's mode of dealing with female difficulties is more traditional, and suggests that it is possible for women to find empowerment in socially acceptable ways. Not only does the force of her calm reason, gracious dignity, and quiet virtue sustain her throughout her trials, but these are the genteel qualities she holds up like a badge in order to escape from [...] difficult situations [...]. Thus, on the one hand, we have Elinor's radical, theoretical, apparently "masculine" approach to the constraints of patriarchy, and, on the other hand, we have Juliet's practical, negotiational, "feminine" approach. (258)

By the end of the novel, it is Juliet's 'feminine' approach that gets rewarded. Juliet wins the story's prize in winning Harleigh's heart. It is nevertheless the case that in most individual incidents in the novel, this passive approach does not serve the heroine well. She is constantly in danger because of the caution she exercises to protect her identity and her precarious reputation. Elinor's ways, we imagine, would have impeded her from being restored to her family with ease, and would furthermore in all probability have precluded her from the possibility of marrying Harleigh. Yet it remains that following Elinor's ways also would have improved her chances of remaining safe, harm lurking as it does in every corner. Juliet's dire situation called for Elinor's radicalism. But what radicalism they share stays between them only in the form of words.

Starting with Rose Marie Cutting in the 1970s, there have been a number of feminist readings of Burney's work, several of which I have cited above. Some critics, however, reject these readings, such as Martha G. Brown who in her article 'Fanny Burney's "Feminism"; Gender or Genre?' attributes feminist interpretations to misperceptions of Burney's 'debts to the romance tradition, from which Burney drew heavily for plot, theme, and character', which makes them 'a matter of genre, rather than gender' (29). Brown concedes only that there may have been a subtle shift in Burney's feminist sensibilities by the time she wrote The Wan- 
derer. There can be no doubt that in the resolution of the novel's events, and in the ultimate reward of Juliet's behaviour, we can note some of Burney's ambivalence toward Elinor and the ideals she espouses.

The novel makes ambiguous the relationship of Elinor's political and social opinions to her unbalanced state of mind. But whether or not we choose to believe that Elinor's madness in the novel completely discredits her principles, it nevertheless is shown that in the whole of the novel, she is in some fundamental way rejected. Elinor's behaviour, unlike that of the angelic and prudent Juliet, is not rewarded by happiness in love and a general increase in good fortunes, but rather by the necessity of a final, sad, resignation of love lost. Although Elinor is rarely directly contradicted in her opinions of women's equality by the characters of the novel, there are textual forces that condemn her behaviour and that seem to require that opinions such as those as she expresses be embodied by a fundamentally disempowered character. Readers who would wish to take Elinor's opinions seriously might be reminded that she is a madwoman, and one condemned to suffer a broken heart. Similarly, one can imagine that if anyone in Burney's time were to attempt to equate Burney's opinions with Elinor's ecstatic protestation, clearly, a defence would be at hand. But in the end, the novel does give clear indication that Elinor cannot be simply dismissed. Her arguments, if not her character, are kept serious throughout the novel. Through her, feminist discourse is given a not implausible voice. Her madness makes the novel's feminism covert, and not unconflicted, but feminism it remains.

\section{VICTORIA KORTES-PAPP \\ Université Laval}

\section{Works Cited}

Austin, Andrea, 'Between Women: Frances Burney's The Wanderer. English Studies in Canada 22, 3 (1996) 253-64.

Brown, Martha G., 'Fanny Burney's "Feminism"; Gender or Genre?' Fettere'd or Free? British Women Novelists, 1670-1815, ed. Mary Anne Schofield and Cecilia Macheski. (Athens/Ohio: Ohio University Press, 1987) 29-39.

The British Critic NS (1 April 1814) 374-86.

Burney, Frances. The Wanderer ed. Margaret Anne Doody, Robert Mack, and Peter Sabor. (New York: Oxford UP, 1991).

Crump, Justine. "'Turning the World Upside Down": Madness, Moral Management, and Frances Burney's The Wanderer' Eighteenth-Century Fiction 10.3 (1998) 325-40. 
Cutting, Rose Marie. 'A Wreath for Fanny Burney's Last Novel' Journal of the College Language Association 20.1 (1976) 57-67

Doody, Margaret Anne. Introduction. The Wanderer. By Frances Burney (New York: Oxford University Press, 1991) vii-xxxvii.

Frances Burney: The Life in the Works (New Brunswick: Rutgers University Press, 1988).

Epstein, Julia. The Iron Pen: Frances Burney and the Politics of Women's Writing (Bristol: Bristol Classical Press, 1989).

Poovey, Mary. The Proper Lady and the Woman Writer: Ideology as Style in the Works of Mary Wollstonecraft, Mary Shelley, and Jane Austen (Chicago: University of Chicago Press, 1984).

Simons, Judy. Fanny Burney (London: Macmillan, 1987). 